\title{
Utility of "Over D1" or D1 Nodal Dissections in Predicting Outcome of Patients with Gastric Adenocarcinoma Treated with Postoperative Concurrent Chemoradiotherapy
}

\author{
Ugur SELEK*, Faruk ZORLU, Gokhan OZYIGIT, Pervin HURMUZ, \\ Suayib YALCIN, Mustafa CENGIZ
}

\begin{abstract}
Hacettepe University Faculty of Medicine, Department of Radiation Oncology, Ankara, TURKEY
* Current affiliation: M.D. Anderson Cancer Center, Department of Radiation Oncology, Houston, TX, U.S.A;

Koc University Faculty of Medicine, Department of Radiation Oncology, Istanbul, TURKEY
\end{abstract}

\begin{abstract}
We retrospectively evaluated the utility "over D1" or D1 dissections on outcome of gastric cancer patients with subsequent postoperative chemoradiotherapy. Sixty-five patients with gastric adenocarcinoma treated with postoperative concurrent chemoradiotherapy were evaluated. Inclusion criteria were total or subtotal gastrectomy with a cut-point of $\geq 10$ nodes dissected in the surgery without scheduled splenectomy and pancreatectomy. Nodal dissections grouped according to Japanese Research Society; N1 stations (1-6) as D1, and dissection of additional stations (7-9) as "over D1". The median follow-up was 30 months. Surgery was total gastrectomy in 32 patients and subtotal in 33. Nodal dissection was D1 in 36 (55.4\%) patients and over D1 in 29 (44.6\%). The 2-year overall, local recurrence free, distant metastasis free, and disease free survivals of the entire group of patients were $83.3 \%, 89.9 \%$, $68.4 \%, 62.5 \%$ respectively. Two year distant metastasis free survival was \%55 for D1 and \%88.5 for "over D1" dissected patients $(p=0.06)$. Overall survival was significantly longer in "over D1" dissected patients (2 year overall survival: $72.3 \%$ for D1 and $96 \%$ for "over D1", $p=0.05$ ). Moreover, disease specific survival was significantly longer in "over D1" dissected patients (2 year disease specific survival: $72.3 \%$ for D1 and 100\% for "over D1", $\mathrm{p}=0.02$ ). No grade $3-4$ acute or late toxicity was observed. In conclusion, our retrospective data showed that over D1 dissected patients treated with concomitant chemoradiotherapy seemed to gain additional survival benefit in comparison to D1 dissected patients in this retrospective cohort with no significant extra toxicity.
\end{abstract}

Keywords: Gastric carcinoma, Radiotherapy, Chemoradiotherapy, Nodal dissection, Chemotherapy

\section{ÖZET}

Postoperatif Kemoradyoterapi Uygulanan mide Kanserli Olgularda D1 ya da "D1'den fazla" Diseksiyon Uygulanmasının Prognoz Üzerinde Retrospektif Değerlendirilmesi

Bu retrospektif çalıșmamızda postoperatif kemoradyoterapi uygulanan mide kanserli olgularda D1 ya da "D1'den fazla" diseksiyon uygulanmasının prognoz üzerindeki etkisi değerlendirilmiştir. Postoperatif kemoradyoterapi uygulanmış 65 mide kanserli olgu değerlendirilmiştir. Total ya da subtotal gastrektomi yapılırken $\geq 10$ lenf nodu diseksiyonu uygulanmıs, planlı splenektomi ve pankreatektomi yapıımamış olgular çalışmaya alınmıştır. 
Nodal diseksiyon Japon Araştırma Derneği kriterlerine göre gruplanmıştır; D1: N1 istasyonlar (1-6) ve "D1'den fazla": ek olarak diğer istasyonların (7-9) diseksiyonu. Ortanca izlem süresi 30 aydır. 32 olgu total ve 33 olgu subtotal gastrektomilidir. D1 nodal diseksiyon 36 (\%55.4) ve "D1'den fazla" 29 (\%44.6) olguya uygulanmıştır. İki yıllık genel, lokal rekürenssiz, uzak metastazsız ve hastalıksız sağkalım oranları sırasıyla \%83.3, \%89.9, \%68.4, \%62.5 olarak tespit edilmiştir. İki yıllık uzak metastazsız sağkalımın D1 için \%55 ve "D1'den fazla" için \%88.5 ( $p=0.06)$ olduğu izlenmiştir. Genel sağkalım "D1'den fazla" grupta istatistiksel olarak daha uzun bulunmuştur (İki yıllık sağkalım, D1: \%72.3 ve "D1'den fazla”: \%96, p= 0.05). Ayrıca, hastalık spesifik sağkalım oranları "D1'den fazla” grupta istatistiksel olarak daha uzun bulunmuştur (Iki yıllık sağkalım, D1: \%72.3 ve "D1'den fazla": \%100, p= 0.02). Ne erken ne geç grad 3-4 toksisite izlenmemiştir. Bu postoperatif eş zamanlı kemoradyoterapi uygulanmış retrospektif kohortta "D1'den fazla" nodal diseksiyon yapıımasının, D1 diseksiyon uygulanmış olgulara göre artmış bir toksisite oluşturmadan sağkalım katkısı olduğu izlenmiştir.

Anahtar Kelimeler: Mide kanseri, Radyoterapi, Kemoradyoterapi, Nodal diseksiyon, Kemoterapi

\section{INTRODUCTION}

The potential for the chemoradiotherapy to improve survival in gastric cancer compared to irradiation alone was first reported by Moertel in 1969 in a series of patients with unresectable tumors. ${ }^{1}$ Combined chemotherapy with 5 -fluorouracil (5-FU) and irradiation has clearly shown a survival benefit as adjuvant therapy following gastrectomy for patients at high risk of recurrence in a large intergroup trial. ${ }^{2}$ This pivotal study has not yet been substantially appreciated in Japan due to the differences in the extent of lymph node dissection.

In this study, we have retrospectively evaluated the outcome of our gastric cancer patients based on D1 and "over D1" dissections with a minimum of 10 nodes dissected with total or subtotal gastrectomy who were treated subsequently with postoperative chemoradiotherapy.

\section{MATERIALS AND METHODS}

\section{Patients}

A retrospective search of the database maintained by the Department of Radiation Oncology was performed to identify all patients with gastric adenocarcinoma who had postoperative concurrent chemoradiotherapy between March 1, 1997, and September 30, 2005. The latter date was chosen to allow a minimum follow-up of 1 year at the time of our analysis. The Hacettepe University institutional review board approved the study design, which involved retrospective review of the patients' medical records and a waiver of informed consent. Patients treated for unresectable disease, recurrent disease, distant metastatic disease identified prior to or during irradiation were excluded from analysis. Inclusion criteria required total or subtotal gastrectomy with a cut-point of $\geq 10$ nodes dissected in the surgery without scheduled splenectomy and pancreatectomy for nodal stations 10-16 and a detailed surgery/pathology report with nodal stations dissected. Nodal stations were grouped according to "The Japanese Research Society for the Study of Gastric Cancer" (JRSGC) guidelines for the standardization of surgical treatment and pathologic evaluation. ${ }^{3}$ In general, the perigastric lymph node stations along the lesser (stations 1,3, and 5) and greater (stations 2, 4, and 6) curvature are group N1, whereas the nodes along the left gastric (station 7), common hepatic (station 8), celiac (station 9), and splenic (stations 10 and 11) arteries are group N2. Minor modifications from this schedule occur depending on the location of the primary tumor. Nodal dissection of N1 stations was defined as D1 and dissection of additional stations were judged as "over D1".

This search identified 65 eligible patients with gastric adenocarcinoma who were treated with postoperative concurrent chemoradiotherapy (CRT) at our center.

\section{Treatment}

We treated the patients using either $6 \mathrm{MV}$ or cobalt60 photons, and the irradiation doses delivered to the tumor bed and regional lymphatics were median $50 \mathrm{~Gy}$ (46-50.4 Gy). All patients were treated with one fraction daily in a continuous course excluding weekends (usually 1.8 Gy-2 Gy daily) with a parallel opposed two-field approach. No patients received preoperative or intraoperative irradiation.

All patients received one to three cycles of systemic chemotherapy prior to chemoirradiation. Patients received concurrently either oral UFT $\left(300 \mathrm{mg} / \mathrm{m}^{2}\right)$ along the whole radiotherapy course excluding we- 


\begin{tabular}{|c|c|c|}
\hline & $\begin{array}{l}\text { Oral UFT Group } \\
(n=18)\end{array}$ & $\begin{array}{l}\text { 5-FU Group } \\
(n=47)\end{array}$ \\
\hline \multicolumn{3}{|l|}{ Gender } \\
\hline Male & 14 & 27 \\
\hline Female & 27 & 20 \\
\hline \multicolumn{3}{|l|}{ Type of Surgery } \\
\hline Total Gastrectomy & 11 & 21 \\
\hline Subtotal Gastrectomy & 21 & 26 \\
\hline \multicolumn{3}{|l|}{ Type of Dissection } \\
\hline D1 & 9 & 27 \\
\hline D2 & 9 & 20 \\
\hline $\begin{array}{l}\text { Median Surgery-RT } \\
\text { interval }\end{array}$ & 83 days & 70 days \\
\hline \multicolumn{3}{|l|}{ Pathology } \\
\hline Adenocarcinoma & 12 & 30 \\
\hline Signet-Ring Cell & 6 & 17 \\
\hline \multicolumn{3}{|l|}{ T Stage } \\
\hline $\mathrm{T} 1$ & 0 & 3 \\
\hline $\mathrm{T} 2$ & 2 & 5 \\
\hline T3 & 13 & 38 \\
\hline $\mathrm{T} 4$ & 3 & 1 \\
\hline \multicolumn{3}{|l|}{ N Stage } \\
\hline NO & 4 & 6 \\
\hline $\mathrm{N} 1$ & 7 & 19 \\
\hline N2 & 5 & 15 \\
\hline N3 & 2 & 7 \\
\hline \multicolumn{3}{|l|}{ AJCC Stage } \\
\hline I & 0 & 2 \\
\hline$\|$ & 6 & 9 \\
\hline IIla & 4 & 15 \\
\hline Illb & 4 & 13 \\
\hline IV & 4 & 8 \\
\hline Median RT Fraction Dose & 2 & 2 \\
\hline Median RT Total Dose & 50 Gy & $50 \mathrm{~Gy}$ \\
\hline
\end{tabular}

ekend days, or intravenous bolus 5-FU $\left(425 \mathrm{mg} / \mathrm{m}^{2}\right)$ with irradiation consisting of one or two cycles usually as a 3-day bolus at the start and last three days of irradiation therapy. The characteristics of these two groups of patients are summarized in Table 1 . After chemoirradiation, all patients received some form of maintenance adjuvant chemotherapy consisting of 5-FU based regimens.

\section{Statistical analysis}

Survival time and tumor control were calculated from the date of initiation of radiotherapy. Actuarial survival analyses were performed using the Kaplan-Meier method. A chi-square test was used to assess differences in patient distribution between groups.

Patient characteristics (age, sex), treatment factors (type of nodal dissection -D1 or D2, number of nodal dissection, number of percent positive nodal involvement, radiotherapy dose, overall radiation treatment time), and tumor characteristics (site, T-stage, and tumor grade) were analyzed as potential prognostic factors using the univariate log-rank method and the multivariate Cox regression method. A p-value $<0.05$ was considered statistically significant.

Patients were recorded as having acute toxicity if they required hospitalization, intravenous hydration, or outpatient parenteral support during treatment. Treatment breaks due to acute toxicity was also recorded as an acute toxicity. Acute and late toxicities were recorded using the Radiation Therapy Oncology Group (RTOG) acute and late morbidity scoring systems.

\section{RESULTS}

\section{Patients}

This cohort included 41 male and 24 female patients with ages ranging from 30 to 75 years (median, 54 years). The median follow-up for the entire group was 30 months (range, 9-101 months).

Except noted below separately, patient characteristics, treatment factors number of nodal dissection, number of percent positive nodal involvement, radiotherapy dose, overall radiation treatment time, type of concomitant chemotherapy), and tumor characteristics (site, T-stage, and tumor grade) were not found to be significant in univariate and multivariate analysis for each title.

\section{Treatment}

In all patients, surgical therapy was initial approach with curative intention. The types of operations performed were total gastrectomy in 32 or subtotal gastrectomy in 33 patients. Distribution of $\mathrm{T}$ and $\mathrm{N}$ 
stage was as follows: T1, 3; T2, 7; T3, 51; T4, 4; and N0, 10; N1, 26; N2, 20; N3, 5. Nodal dissection was D1 in $36(55.4 \%)$ patients and over D1 in 29 (44.6\%). Median number of nodes dissected was 19 (range, 11-77 nodes).

Eighteen patients received concomitant oral UFT, and 47 patients were given 5-FU. There was generally no significant difference between oral UFT and 5-FU groups with regard to the characteristics of patients and prognostic factors (Table 1). Radiotherapy began from 30 to 131 days after surgery (median $=72$ days). The median fractionated radiation dose was $50 \mathrm{~Gy}$ (range, 46-50.4 Gy).

\section{Local control and Survival Rates}

The 2-year local recurrence free survival of the entire group of patients was $89.9 \%$. The 2 -year distant metastasis free survival of the entire group of patients was $68.4 \%$.

Distant metastasis was frequent in patients with D1 dissection (cumulative; $15 / 36$ patients vs. $5 / 29$ patients); and 2 year distant metastasis free survival was $55 \%$ for D1 and $88.5 \%$ for "over D1" dissected patients $(\mathrm{p}=0.06)$.

Cumulatively, six patients had local and 20 had distant failure, while 11 patients had disease specific death. The 2-year overall survival of the entire group of patients were $83.3 \%$. Overall survival was significantly longer in "over D1" dissected patients (cumulative; $10 / 36$ patients vs. 2/29 patients); and 2 year overall survival was $72.3 \%$ for D1 and $96 \%$ for "over D1" dissected patients $(\mathrm{p}=0.05)$.

Disease specific survival was significantly longer in "over D1" dissected patients (cumulative; 10 deaths/36 patients vs. $1 / 29$ patients); while 2 year disease specific survival was $72.3 \%$ for D1 and $100 \%$ for "over D1" dissected patients $(\mathrm{p}=0.02)$.

\section{Toxicity}

No serious grade 3-4 acute or late toxicity was reported.

\section{DISCUSSION}

The optimal regional dissection extent during gastrectomy for gastric adenocarcinoma continues to be debated. We have retrospectively evaluated the uti- lity of D1 and D2 dissections on outcome with a minimum of 10 nodes dissected with total or subtotal gastrectomy who were treated subsequently with postoperative chemoradiotherapy. D2 dissection revealed a superior overall survival over D1 in our cohort with standard postoperative concurrent chemoradiotherapy.

In the United States, MacDonald et al. reported a large intergroup trial (INT116) comparing only surgery versus surgery and post-operative chemoradiation with median survival of 27 months and 36 months, respectively $(\mathrm{p}<0.001){ }^{2}$ This study mainly fulfills the required encouragement to enroll patients into adjuvant chemoradiotherapy, however did not answer the question of which group of patients could get the best survival benefit clearly. No other randomized studies were specifically designed to answer this question in the chemoradiotherapy era.

As the uncertainty of impact of extent of nodal dissection on survival arisen, Smith et al rigorously analyzed a large US population database and revealed that there is greatest survival difference at 10 lymph nodes examined in their cut-point analysis with persistence of a significant survival advantage for cut points at up to $40 \mathrm{LNs}$, always in favor of more LNs examined. ${ }^{4}$ They emphasized that for every 10 extra nodes dissected, survival improved by $5.7 \%$ to $11 \%$ in patients requiring adjuvant treatment (T1-2N1, T3N0, T3N1). This point of view directed us to identify our cohort with at least 10 nodes dissected.

D1 versus D2 dissection is a long run debate and in the last decade, D2 dissections have become more popular in Western countries as well. This have generated a distinct amount of nonrandomized studies reporting postoperative mortality rates of $3 \%$ to $8 \%$, morbidity rates of $22 \%$ to $38 \%$, and 5 -year survival rates of $26.3 \%$ to $55 \%$ for D2 dissections..$^{5-7}$ The large variability in the reported results mainly depended on the different definitions of D2 dissections in most series and the abandonment of pancreatico-splenectomy in later series. D2 dissection could not be clearly demonstrated in Western countries, in contrary to the results reported from Japan. Two small studies showed an increase in morbidity without survival benefit with more extensive surgery. ${ }^{8,9}$ Two large randomized multi-center studies comparing D1 and D2 dissections have been 
published: the Dutch Gastric Cancer Trial $(\mathrm{DGCT})^{10-13}$ and the British Medical Research Council Gastric Cancer Surgical Trial (MRC). ${ }^{14}$

In the MRC trial, 400 patients with gastric adenocarcinoma were randomly assigned (200 to D1 and 200 to D2). Postoperative mortality (13\% v $6.5 \%$ for D1) and postoperative complications ( $46 \%$ v $28 \%$ for D1) were significantly higher in the D2 group, while 5-year survival rates were similar (35\% for D1 and 33\% for D2). ${ }^{14}$ In the Netherlands trial, 80 hospitals participated in the DGC randomized trial to compare D1 or D2 lymph node dissection, and 711 patients (380 with D1 and 331 with D2) underwent the allocated treatment with curative intent by using the definition of D1 and D2 dissections in the guidelines of the JRSGC..$^{15} \mathrm{D} 2$ patients had higher postoperative mortality $(10 \% \mathrm{v} 4 \%$ for D1), significantly more complications ( $43 \%$ v $25 \%$ for D1) and prolonged hospitalization for patients after D2 dissection. At eleven years, survival rates were similar (30\% for D1 and 35\% for D2). ${ }^{11}$ However, survival rates seem improved if hospital deaths are excluded (32\% for D1; 39\% for D2), while the relapse risk decreased borderline significant in the $\mathrm{D} 2$ dissection group ( $\mathrm{p}=0$.07). Remarkable is significant survival improvement in N2 disease patients if patients with hospital mortality are excluded, and also relapse advantage for patients with a D2 dissection $(\mathrm{p}=0.01)$. These two randomized trials show the same tendency as the postoperative mortality and morbidity in both trials were significantly higher in the D2 dissection group. Besides, there was no survival advantage for extended (D2) dissections and therefore it was concluded that there is no support for standard extended (D2) lymph node dissections in Western patients with gastric cancer. ${ }^{11,14}$

Splenectomy and pancreatectomy are important risk factors for morbidity and hospital mortality after D2 dissection, with a significant adverse effect on survival as well. ${ }^{10-14}$ The main motive in D2 dissection to do pancreatectomy and splenectomy is to adequately dissect lymph node stations 10 and 11 . If any metastases found in these dissected lymph nodes, a poorer prognosis is expected. Therefore, the relevance of the dissection of these nodes has to be questioned as the survival benefit is small and morbidity and hospital mortality are significantly increased. In the DGCT the relative risk ratio for morbidity and mortality is significantly higher than 1.0 for D2 dissections, splenectomy, pancreatectomy, and age more than 70 years (mortality only). ${ }^{11}$ Subgroup analysis of patients in the DGCT who had no splenectomy $(n=546)$, the complications still occurred more frequently in D2 than in D1 (35\% and 23\% respectively), but for these patients, mean survival is significantly better in the D2 dissection group (6.67 years) compared with the D1 dissection group (5.77 years). Again patients who had no pancreatectomy $(n=603)$ morbidity as well as hospital mortality are significantly higher in the D2 group, but mean survival is also significantly better (6.43 years v 5.67 years). On this base, a recent Italian study counterbalancing comments on the Dutch and English trials that too many centers with too little volume and experience compared D1-versus-D2. A main difference from the former trials was that the pancreas preserving D2 dissection being performed (D1, 76; D2, 86 patients). Overall complications recovered as morbidity was reported to be $10.5 \%$ and $16.3 \%$, and mortality was $1.3 \%$ and $0 \%$, respectively. ${ }^{16}$ Based on these findings a so-called "over-D1" lymphadenectomy might be recommended, because a survival benefit of an extended lymph node dissection seems to appear if morbidity and mortality increasing procedures like elective pancreatectomy and splenectomy can be avoided. ${ }^{17} \mathrm{~A}$ randomized English study also supports these findings for patients with stage II and III disease. In our cohort, overall survival was significantly longer in "over D1" dissected patients with a 2 year overall survival of $72.3 \%$ for D1 and $96 \%$ for "over D1" dissection who were treated with adjuvant chemoradiotherapy. Again, disease specific survival was also significantly longer in our "over D1" dissected patients (2 year DSS: $72.3 \%$ for D1 and $100 \%$ for "over D1" dissection).

In the analysis of the treatment variables in the current series, we have revealed that the type of dissection was noteworthy in the adjuvant chemoradiotherapy era. It did appear that patients treated with D1 dissection had lower overall survival when compared to those treated with "over D1" dissection in our cohort with well known drawbacks due to the retrospective nature and limited number of patients in this analysis. Therefore, while we report our results in this cohort, we believe the necessity of verification in a large scale prospective study. 
Conflict of Interest: We do not have any conflict of interests using copyrighted information, or are using patient photos. We have not received from any commercial entity any payments or any pecuniary, in kind, or other professional or personal benefits including stock, honoraria, or royalties (collectively, "Benefits") or any commitment or agreement to provide such Benefits that were related in any way to the subject of the Work or the research that we conducted in connection with the Work.

\section{REFERENCES}

1. Moertel CG, Childs DS, Jr., Reitemeier RJ, et al. Combined 5-fluorouracil and supervoltage radiation therapy of locally unresectable gastrointestinal cancer. Lancet 2: 865-867, 1969.

2. Macdonald JS, Smalley SR, Benedetti J, et al. Chemoradiotherapy after surgery compared with surgery alone for adenocarcinoma of the stomach or gastroesophageal junction. N Engl J Med 345: 725 730, 2001.

3. Kajitani T. The general rules for the gastric cancer study in surgery and pathology. Part I. Clinical classification. Jpn J Surg 11: 127-139, 1981.

4. Smith DD, Schwarz RR, Schwarz RE. Impact of total lymph node count on staging and survival after gastrectomy for gastric cancer: data from a large US-population database. J Clin Oncol 23: 7114-7124, 2005.

5. Siewert JR, Bottcher K, Roder JD, et al. Prognostic relevance of systematic lymph node dissection in gastric carcinoma. German Gastric Carcinoma Study Group. Br J Surg 80: 1015-1018, 1993.

6. Wanebo HJ, Kennedy BJ, Winchester DP, et al. Gastric carcinoma: does lymph node dissection alter survival? J Am Coll Surg 183: 616-624, 1996.

7. de Manzoni G, Verlato G, Guglielmi A, et al. Prognostic significance of lymph node dissection in gastric cancer. Br J Surg 83: 1604-1607, 1996.

8. Dent DM, Madden MV, Price SK. Randomized comparison of R1 and R2 gastrectomy for gastric carcinoma. Br J Surg 75: 110-112, 1988.

9. Robertson CS, Chung SC, Woods SD, et al. A prospective randomized trial comparing $\mathrm{R} 1$ subtotal gastrectomy with R3 total gastrectomy for antral cancer. Ann Surg 220: 176-182, 1994.

10. Hartgrink $\mathrm{HH}$, van de Velde CJ. Status of extended lymph node dissection: locoregional control is the only way to survive gastric cancer. J Surg Oncol 90: 153165, 2005.
11. Hartgrink $\mathrm{HH}$, van de Velde CJ, Putter $\mathrm{H}$, et al. Extended lymph node dissection for gastric cancer: who may benefit? Final results of the randomized Dutch gastric cancer group trial. J Clin Oncol 22: 2069-2077, 2004.

12. Bonenkamp JJ, Hermans J, Sasako M, et al. Quality control of lymph node dissection in the Dutch randomized trial of D1 and D2 lymph node dissection for gastric cancer. Gastric Cancer 1: 152-159, 1998.

13. Bonenkamp JJ, Songun I, Hermans J, et al. Randomised comparison of morbidity after D1 and D2 dissection for gastric cancer in 996 Dutch patients. Lancet 345: 745-748, 1995.

14. Cuschieri A, Weeden S, Fielding J, et al. Patient survival after D1 and D2 resections for gastric cancer: long-term results of the MRC randomized surgical trial. Surgical Co-operative Group. Br J Cancer 79: 15221530, 1999.

15. Bunt AM, Hermans J, Boon MC, et al. Evaluation of the extent of lymphadenectomy in a randomized trial of Western- versus Japanese-type surgery in gastric cancer. J Clin Oncol 12: 417-422, 1994.

16. Degiuli $M$, Sasako $M$, Calgaro $M$, et al. Morbidity and mortality after D1 and D2 gastrectomy for cancer: interim analysis of the Italian Gastric Cancer Study Group (IGCSG) randomised surgical trial. Eur J Surg Oncol 30: 303-308, 2004.

17. Jansen EP, Boot H, Verheij M, et al. Optimal locoregional treatment in gastric cancer. J Clin Oncol 23: 4509-4517, 2005.

\section{Correspondence}

Dr. Faruk ZORLU

Hacettepe Üniversitesi Tıp Fakültesi

Radyasyon Onkolojisi Anabilim Dalı

06100 Sinhiye, ANKARA / TURKEY

Tel: (+90.312) 3052900

Fax: (+90.312) 3092914

e-mail: : fzorlu@hacettepe.edu.tr 